\title{
The insulinotropic effect of endothelin-1 is mediated by glucagon release from the islet alpha cells
}

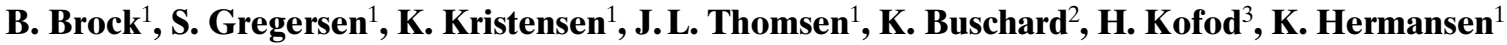 \\ ${ }^{1}$ Department of Endocrinology and Metabolism, Aarhus University Hospital, Aarhus University, Aarhus, Denmark \\ ${ }^{2}$ Bartholin Institute, Community Hospital, Copenhagen, Denmark \\ ${ }^{3}$ Department of Cell Biology, Novo Nordisk, Bagsværd, Denmark
}

\section{Abstract}

Aims/hypothesis. The circulating concentrations of endothelin-1 (ET-1), a peptide derived from endothelium, are increased in hypertension and diabetes. Endothelin-1 has recently been shown to be an insulinotropic agent. The mechanism of action of endothelin1 on the endocrine pancreas has not yet been clarified. Methods. We investigated the action of endothelin-1 on the insulin secretion, the binding of ${ }^{125}$ I-ET- 1 to beta cells as well as its effects on purified beta and non-beta cells from normal rats. The expression of endothelin receptors in alpha- and beta-cell lines and in normal rat islets was also studied.

Results. First, we studied the effects of endothelin-1 on insulin secretion from beta-cell lines (INS-1, $\beta$ TC3 and MIN6). At all endothelin-1 concentrations applied ( $1 \mathrm{pmol} / 1$ to $1 \mu \mathrm{mol} / \mathrm{l})$ no change in insulin secretion was found. Ligand-binding experiments on $\beta$ TC3 cells showed no specific binding of ${ }^{125}$ I-ET-1.
A prominent expression of $\mathrm{ET}_{\mathrm{A}}$-receptor mRNA in an alpha-cell line ( $\alpha \mathrm{TC1} .9)$ and in normal rat islets was found whereas no expression was found in INS1 cells. No influence of endothelin- $1(1 \mu \mathrm{mol} / \mathrm{l})$ on insulin secretion stimulated by glucose was detected from purified beta cells. Endothelin-1-(100 nmol/1) increased, however, both insulin and glucagon secretion from a mixture of purified beta and non-beta cells indicating that alpha cells seem to have a key role for the action of ET-1 on insulin secretion.

Conclusion/interpretation. The insulinotropic impact of endothelin-1 is not caused by a direct action on the beta cells but seems to be mediated by a paracrine action, probably secondary to enhanced release of glucagon from the endothelin receptor positive alpha cells. [Diabetologia (1999) 42: 1302-1307]

Keywords Endothelin-1, insulin secretion, glucagon secretion, flow cytometry, alpha cell, beta cell, clonal cell line, endothelin receptor, gene expression.
Endothelin-1 (ET-1) is a peptide derived from endothelium and is part of a family of potent endogenous vasoconstrictor peptides [1]. It has been implicated in the pathogenesis of vascular damage in hypertension and diabetes mellitus. Consequently some studies have shown increased concentrations of circulating ET-1 in both Type I (insulin-dependent) and

Received: 2 April 1999 and in revised form: 4 June 1999

Corresponding author: S. Gregersen, MD, PhD, Department of Endocrinology and Metabolism, Aarhus Amtssygehus, Aarhus University Hospital, Tage-Hansensgade 2, 8000 Aarhus C, Denmark

Abbreviations: ET-1, endothelin-1.
Type II (non-insulin-dependent) diabetes mellitus [2-4] but others have not been able to show such a relation [5]. Recently, we showed that ET-1 is capable of potentiating insulin secretion, stimulated by glucose, from isolated mouse islets [6] pointing to a direct action on the beta cells. The finding that ET-1 possesses the ability to change glucose metabolism either secondarily to increasing the circulating concentrations of insulin $[7,8]$ or by modulation of insulin sensitivity $[9,10]$ underline the importance of clarifying how this peptide influences the endocrine pancreas. The question asked here was whether this peptide potentiates insulin secretion directly by action on the islet beta cells or indirectly by interaction with other islet cell types, e.g. the alpha cells. We therefore stud- 
ied whether ET-1 modulates insulin secretion, stimulated by glucose, from beta cells and from purified rat islet cells. To study the possible existence of ET receptors on the beta cells we also did ligand-binding experiments and used reverse transcriptase polymerase chain reaction (RT-PCR) to study the expression of ET-receptor mRNA.

\section{Materials and methods}

Preparation and incubation of purified islet cells. Islets were isolated from male Lewis rats weighing 170-180 g (M\&B, Denmark) using the collagenase digestion technique. They were incubated overnight at $4{ }^{\circ} \mathrm{C}, 95 \%$ air $/ 5 \% \mathrm{CO}_{2}$ in RPMI 1640 (Gibco BRL, Paisley, UK) supplemented with $10 \%$ fetal calf serum (Life Technologies, Md., USA). After treatment with trypsin $(0.02 \mathrm{mg} / \mathrm{ml}$; Boehringer Mannheim, Mannheim, Germany) at $4{ }^{\circ} \mathrm{C}$ the cells were sorted by a fluorescence-activated cell sorting system (FACStar Plus, Becton Dickinson, Mountain View, Calif., USA) to give purified beta and nonbeta cells [11]. For incubation experiments with ET-1 the purified beta cells were seeded at a density of 0.1 million cells/ vial in 96-well plates (NUNC, Roskilde, Denmark). In experiments with mixtures of beta and non-beta cells the density was 62000 beta /38000 non-beta cells per vial. After overnight culture at $37^{\circ} \mathrm{C}, 95 \%$ air/ $5 \% \mathrm{CO}_{2}$ in RPMI 1640 supplemented with $10 \%$ fetal calf serum the cells were washed with a modified Krebs-Ringer Buffer (KRB) and used for incubation studies. The modified KRB contained $125 \mathrm{mmol} / \mathrm{l}$ $\mathrm{NaCl}, 5.9 \mathrm{mmol} / \mathrm{l} \mathrm{KCl}, 1.2 \mathrm{mmol} / \mathrm{l} \mathrm{MgCl}_{2}, 1.28 \mathrm{mmol} / 1 \mathrm{CaCl}_{2}$, $25 \mathrm{mmol} / \mathrm{l}$ HEPES and human serum albumin (Boehringer Mannheim), $\mathrm{pH}$ 7.4. Pre-incubations were carried out for $60 \mathrm{~min}$ at $37^{\circ} \mathrm{C}, 95 \%$ air $/ 5 \% \mathrm{CO}_{2}$ in $200 \mu \mathrm{l}$ of the modified KRB supplemented with $3.3 \mathrm{mmol} / 1$ glucose followed by incubations for $60 \mathrm{~min}$ at $37^{\circ} \mathrm{C}$ in $95 \%$ air/ $5 \% \mathrm{CO}_{2}$ in $200 \mu \mathrm{l}$ of the modified KRB supplemented with glucose and ET-1 (Sigma Chemical, St. Louis, Mo., USA). After this $150 \mu \mathrm{l}$ of the incubation medium was removed for analyses of insulin and glucagon.

Incubation studies on cell lines. The INS-1 cells [12] were grown in monolayer in a modified RPMI 1640 medium (Gibco) supplemented with $10 \%(\mathrm{v} / \mathrm{v})$ fetal calf serum $10 \mathrm{mmol} / \mathrm{l}$ HEPES, $100 \mathrm{IU} / \mathrm{ml}$ penicillin, $100 \mathrm{mg} / \mathrm{ml}$ streptomycin (all Life Technologies), $1 \mathrm{mmol} / \mathrm{l}$ sodium pyruvate and $50 \mathrm{mmol} / \mathrm{l}$ $\beta$-mercaptoethanol in 24-well plates (NUNC). The MIN6-cells [13] were grown in RPMI 1640 and $\beta$ TC3-cells [14] and $\alpha$ TC1.9 cells [15] in DMEM (Gibco), both supplemented with $10 \%$ fetal calf serum. The cells were seeded at a density of 200000 cells 2 days before the incubation experiments. The incubation experiments were carried out as described above for purified islet cells.

Ligand binding. We used $\beta$ TC3 cells for competition studies with ${ }^{125}$ I-ET-1 and cold ET-1. The cells were seeded onto 6well plates 2 days before the experiments at a density of 1000000 cells per well. The wells were rinsed with a binding buffer containing $130 \mathrm{mmol} / \mathrm{l} \mathrm{NaCl}, 4.7 \mathrm{mmol} / \mathrm{l} \quad \mathrm{KCl}$, $1.4 \mathrm{mmol} / 1 \mathrm{MgSO}_{4}, 2.5 \mathrm{mmol} / 1 \mathrm{NaH}_{2} \mathrm{PO}_{4}, 10 \mathrm{mmol} / \mathrm{l} \mathrm{HEPES}$, $1 \mathrm{mmol} / \mathrm{l}$ EGTA and $3.0 \mathrm{mmol} / \mathrm{l} D$-glucose before the binding experiments. The experiments were carried out for $120 \mathrm{~min}$ at $4^{\circ} \mathrm{C}$ in the above mentioned binding buffer supplemented with human serum albumin (Boehringer) and $50000 \mathrm{cpm} / \mathrm{ml}$ of ${ }^{125}$ I-ET-1 or ${ }^{125}$ I-glucagon (both with a specific activity of 74
$\mathrm{TBq} / \mathrm{mmol}$; Amersham International, Bucks, UK). After rinsing the cells with ice-cold binding buffer, $1.0 \mathrm{ml} \mathrm{NaOH}$ was added and the plates were left for $30 \mathrm{~min}$. The solution was then used for $\gamma$-counting and subsequent protein analysis. The binding of ${ }^{125} \mathrm{I}$-glucagon and its displacement by cold glucagon (Sigma) was used as control.

$R T-P C R$ assay for detection of $E T_{A}$-receptor $m R N A$. We isolated RNA from rat islets, the beta-cell line INS-1 and from an alpha-cell line $\alpha \mathrm{TC} 1.9$ using TriZol reagent (Gibco). The $\mathrm{ET}_{\mathrm{A}^{-}}$ receptor primers used in the polymerase chain reaction (PCR) spanned a product of 310 base pairs. The sense ETprimer (5'GCCATTGAAATCGTCTCCATC) corrresponds to mouse ET-receptor cDNA 16 to 36 and the antisense (5'TTTGCCACTTCTCGACGCTG) corresponds to basepair 307 to 326 (GeneBank Accession no. L20340). The reverse transcriptase was done using random hexamer primers. The cDNA product was amplified by addition of AmpliTaq Gold DNA polymerase (Roche Molecular Systems, Brandsburg, N. J., USA). Each cycle of amplification consisted of denaturation at $95^{\circ} \mathrm{C}$ for $1 \mathrm{~min}$, annealing at $58^{\circ} \mathrm{C}$ for $1 \mathrm{~min}$ and extension for $2 \min \left(74^{\circ} \mathrm{C}\right)$. We ran 36 cycles and the final cycle was terminated by a 6 -min extension period $\left(74^{\circ} \mathrm{C}\right)$. Finally, $8 \mu \mathrm{l}$ of the PCR product was loaded on $2 \%$ agarose gel, stained with ethidiumbromide and photographed. A similar protocol was used for negative controls except that the reverse transcriptase was omitted.

Insulin and glucagon assays. Insulin was measured by radioimmunoassay with a guinea-pig, anti-porcine insulin antibody and mono- ${ }^{125}$ I-(Tyr A14)-labelled human insulin as tracer and rat insulin as standard. Free and bound radioactivity was separated using ethanol. Glucagon was measured by radioimmunoassay (Linco Res., Mo., USA). Endothelin-1 in the concentrations studied did not interfere with the assays.

Protein analysis. The cells were lysed in $0.1 \mathrm{~mol} / 1 \mathrm{NaOH}$ and total protein was measured by Bratfords method using BioRad Protein assay Dye reagent (Bio-Rad Laboratories, Hercules, Calif., USA).

Statistics. To avoid variation from day to day in the insulin output from the purified islet cells, the results were related to the mean output on that particular day. The data hereby obtained were analysed using Students unpaired $t$ test. Insulin secretion from beta-cell lines was analysed by ANOVA and Newman-Keuls test. The level of significance was set at $p<0.05$. Results are expressed as means \pm SEM.

\section{Results}

Effects of ET-1 on insulin secretion from clonal betacell lines. The effect of ET-1 on insulin secretion from INS-1 cells was studied in the presence of $16.7 \mathrm{mmol} / \mathrm{l}$ glucose (Fig. 1$)$. Glucose $(16.7 \mathrm{mmol} / \mathrm{l})$ stimulated insulin secretion by approximately $120 \%$ compared with $3.3 \mathrm{mmol} / \mathrm{l}$ glucose $(p<0.01)$. When applied at $16.7 \mathrm{mmol} / \mathrm{l}$ glucose ET-1 (1 pmol/1 to $1 \mu \mathrm{mol} / \mathrm{l})$ did not change the insulin secretion. In contrast, as expected, carbacholin $(100 \mu \mathrm{mol} / \mathrm{l})$ potentiated insulin secretion stimulated by glucose $(p<0.05)$. In addition, we studied the effects of ET-1 on insulin secretion stimulated by glucose from two other beta- 


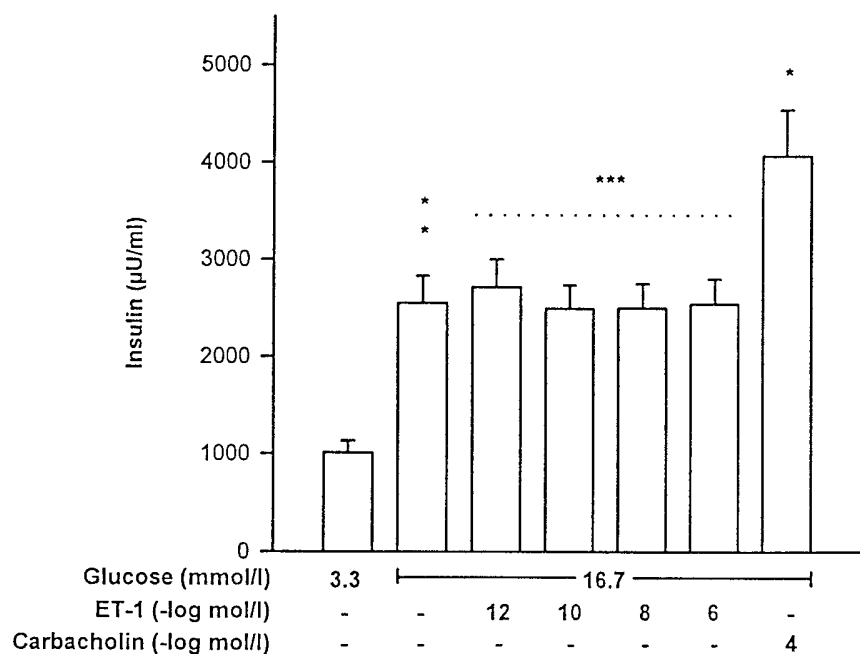

Fig. 1. Effects of ET-1 ( $1 \mathrm{pmol} / \mathrm{l}$ to $1 \mu \mathrm{mol} / \mathrm{l})$ and carbacholine $(100 \mu \mathrm{mol} / \mathrm{l})$ on insulin secretion from INS-1 cells incubated for $60 \mathrm{~min}$ at 3.3 or $16.7 \mathrm{mmol} / \mathrm{l}$ glucose. The columns show means \pm SEM from four separate experiments each containing eight single incubations. ${ }^{*} p<0.05$ compared with $16.7 \mathrm{mmol} / \mathrm{l}$ glucose itself, $* * p<0.01$ compared with $3.3 \mathrm{mmol} / 1$ glucose itself, $* * *$ not significantly different from $16.7 \mathrm{mmol} / \mathrm{l}$ glucose itself

cell lines, $\beta$ TC3 and MIN6 with identical observations, i.e. there was no change in insulin secretion (Table 1).

Studies on insulin secretion from purified beta cells. When expressed in arbitrary units (per cent change from mean of the entire data set, (see Methods section), an increase in glucose from 3.3 to $16.7 \mathrm{mmol} / \mathrm{l}$ stimulated insulin secretion two-fold $(0.57 \pm 0.05$ vs. $61.19 \pm 0.13 ; p<0.05)$ from the purified normal rat beta cells. When ET-1 (100 nmol/l) was added in the presence of $16.7 \mathrm{mmol} / \mathrm{l}$ glucose no change in insulin release could be detected $(1.19 \pm 0.13$ vs. $1.21 \pm$ $0.97)$. The number of single incubations were six to nine done in six separate experiments.

Studies on insulin and glucagon secretion from mixed, purified, beta and non-beta cells. When purified beta and non-beta cells were mixed at a ratio of $5: 3$ at the prevailing glucose concentration of $16.7 \mathrm{mmol} / \mathrm{l}$, ET-1 (100 nmol/l) potentiated both in- sulin (in arbitrary units, see above) from $1.00 \pm 0.05$ to $1.28 \pm 0.09 \quad(p<0.05)$ and glucagon secretion from $0.84 \pm 0.03$ to $1.06 \pm 0.09(p<0.05)$. The number of single incubations were 12-13 done in eight separate experiments.

Displacement studies. Displacement of ${ }^{125}$ I-ET-with cold ET-1 on $\beta$ TC3-cells was also carried out. There was a lack of displacement of ${ }^{125}$ I-ET-with ET-1 at the concentrations used (10 pmol/l- $1 \mu \mathrm{mol} / \mathrm{l})$ (Fig. 2A). The relatively low total binding and the lack of displacement show that there is no specific binding of ${ }^{125} \mathrm{I}-\mathrm{ET}$-to the $\beta \mathrm{TC} 3$ cells. As a positive control we found a clear displacement of ${ }^{125} \mathrm{I}$-glucagon by cold glucagon ( $1 \mathrm{pmol} / \mathrm{l}$ to $1 \mu \mathrm{mol} / \mathrm{l})$ (Fig. $2 \mathrm{~B})$.

$R T$-PCR for $E T_{A}$-receptor $m R N A$. A prominent signal appeared at the appropriate size in the two lanes where cDNA from $\alpha$ TC1.9-cells was loaded (lanes 3 and 4) (Fig.3). No signal was seen in INS-1 cells (lanes 5 and 6) whereas normal rat islets also showed a clear signal for $\mathrm{ET}_{\mathrm{A}}$-receptor mRNA (lanes 7 and $8)$. No signal was seen in the lane where the reverse transcriptase was omitted (lane 2).

\section{Discussion}

Endothelin-1, an ubiquitous peptide, has been proposed to be involved in many different regulatory functions both in the central nervous system as a neurotransmitter [16] and in the periphery as a potent vasoactive substance derived from endothelium [1]. This peptide can modulate the release of several hormones such as growth hormone [17], parathyroid hormone [18] and testosterone [19, 20]. Regarding the potential impact of ET-1 on the endocrine pancreas, recent work has shown the capability of ET-1 to increase insulin concentrations in vivo in the rat $[7,8]$ and dog [21]. This peptide possibly also changes glucose metabolism immediately by lowering insulin sensitivity as shown in healthy humans [10] and rats [9]. The insulin sensitivity in humans has, however, also been reported unchanged in response to ET-1 infusion [22]. We have recently shown that ET-1 potentiates insulin release, stimulated by glucose, from the islets [6]. A direct effect of ET-1 on

Table 1. Effects of ET-1 ( $1 \mathrm{pmol} / \mathrm{l}$ to $1 \mu \mathrm{mol} / \mathrm{l})$ on insulin secretion from the beta-cell lines MIN 6 and $\beta$ TC 3 incubated at 3.3 or $16.7 \mathrm{mmol} / \mathrm{l}$ glucose

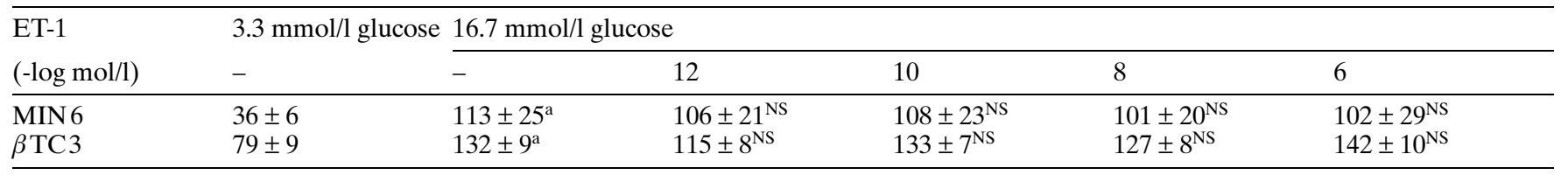

Insulin given in $\mu \mathrm{U} / \mathrm{ml}$, means \pm SEM from a total of 8-12 single incubations of clonal cells done in two experiments.

${ }_{p}^{a} p<0.01$ (different from $3.3 \mathrm{mmol} / \mathrm{l}$ glucose)

${ }^{\mathrm{NS}}$ not different from $16.7 \mathrm{mmol} / \mathrm{l}$ glucose per $\mathrm{s}$ 


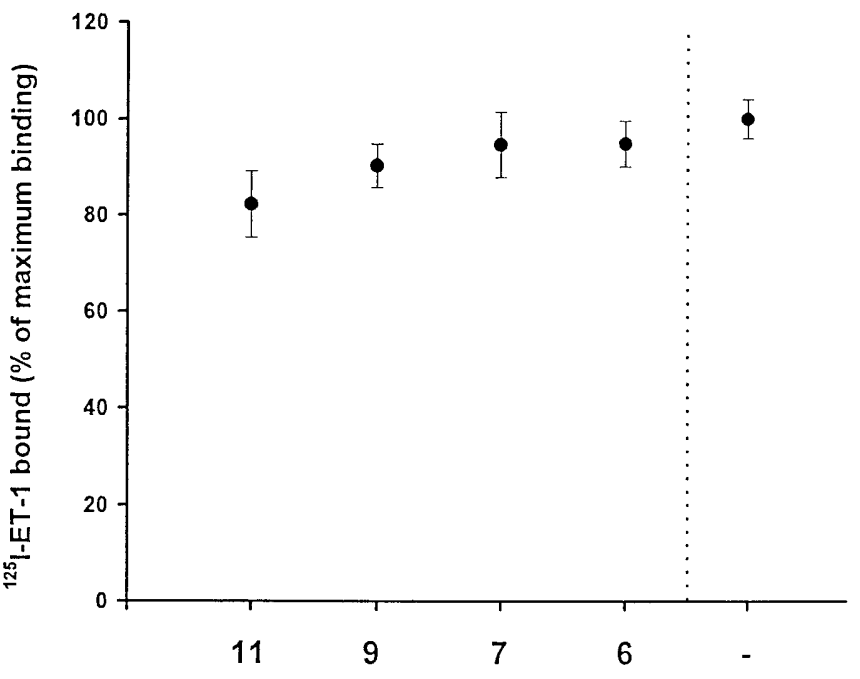

A

ET-1 (-log $\mathrm{mol} / \mathrm{l})$

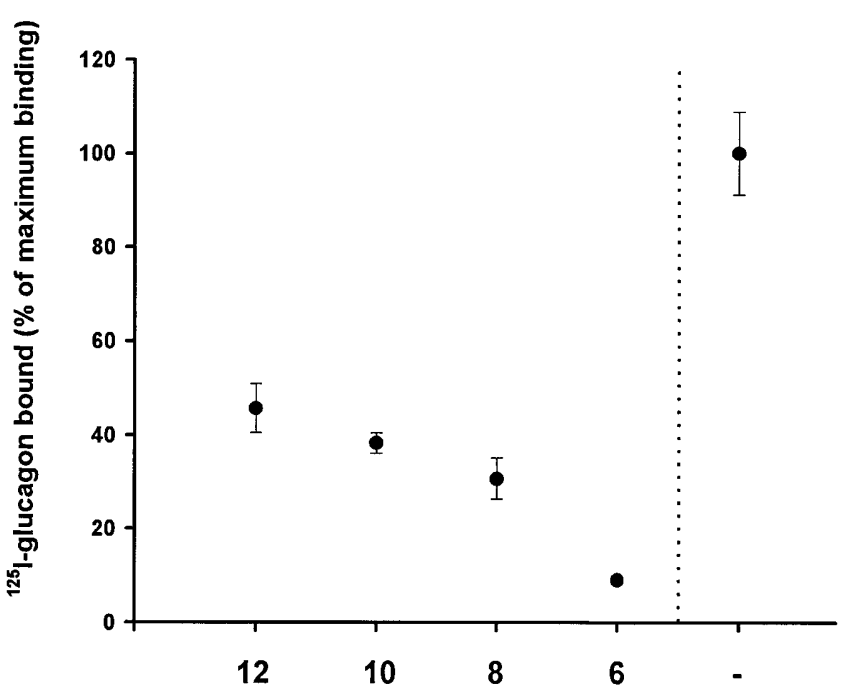

B

Glucagon (-log mol/l)

Fig. 2 A, B. Displacement from $\beta$ TC3 cells of $(\mathbf{A})^{125}$ I-ET-1 by cold ET-1 (10 pmol/l to $1 \mu \mathrm{mol} / \mathrm{l})$ or $(\mathbf{B}){ }^{125}$ I-glucagon by cold glucagon $(1 \mathrm{pmol} / \mathrm{l}$ to $1 \mu \mathrm{mol} / \mathrm{l})$. Each point on the curves represents means \pm SEM from triplicates in three separate experiments

the islet beta cells would seem to be a probable explanation underlying the immediate insulinotropic effect. Note that this study shows, however, that ET-1 is not able to change insulin release from three different beta cell lines, i. e. INS-1, MIN6 and $\beta$ TC3 cells. Being aware of the risk of artefactual findings in clonal cell lines, we included studies in fluorescence-activated cell sorting purified islet cells from normal rats. Using the normal, purified beta cells, we obtained similar results, i.e. ET-1 did not change insulin secretion from beta cells. Furthermore, our receptor-binding experiments using ${ }^{125}$ I-ET-1 showed a low total binding of ${ }^{125}$ I-ET-1 to $\beta$ TC 3 cells and no displacement by cold ET-1 supporting ET-1 receptors not being present on beta cells. As a control we showed that ${ }^{125}$ I-glucagon was displaced by cold glucagon. Glucagon receptors have been shown on beta-cell lines [23].

To gain further insight, we supplemented the ligand-binding experiments with studies on the expression of $\mathrm{ET}_{\mathrm{A}}$-receptor mRNA. Using RT-PCR we found that $\mathrm{ET}_{\mathrm{A}}$-receptor mRNA exists in the alphacell line, $\alpha \mathrm{TC1}$.9, but not in the beta-cell line, INS-1. We also showed that mRNA for the $\mathrm{ET}_{\mathrm{A}}$ receptor is expressed in normal rat islets. Similar results were obtained using islets from normal mice (unpublished results). It is well known that ET receptors are present on endothelial cells [20] apparently, however, a significant part of the specific mRNA detected in islets originates from alpha cells.

Taken together, our results seem to rule out that this peptide has any direct action on the islet beta cells. Instead our findings point to the possibility that another islet cell type might be involved in the insulin secretion induced by ET-1 from intact islets. This is rendered probable by the finding that ET-1 was capable of stimulating insulin secretion when purified rat beta and non-beta cells were mixed. The purified non-beta cells consisted mainly (approximately $90 \%$ ) of alpha cells [11] and it is therefore likely that the concomitant presence of alpha and beta cells is a prerequisite for insulin secretion induced by ET-1. In line with this we showed a slight, but statistically significant, increase in glucagon secretion from mixed beta and non-beta cells in response to stimulation with ET-1 at high glucose. This finding seems at variance with experiments in vivo in rats where continuous ET-1 infusion immediately suppresses plasma pancreatic glucagon concomitant with decreased blood glucose and delayed increments in plasma insulin [7]. Those authors found that ET-1 enhanced insulin concentrations despite a preceding suppression of glucagon and blood glucose concentrations. The complexity of in vivo experimental conditions and the relatively high glucose concentration applied in our present study could explain this discrepancy between effects of ET-1 on glucagon secretion in vitro and in vivo.

Only scanty information exists on the mechanism of action of ET-1 on insulin release. A role for nitric oxide in insulin secretion induced by ET-1 in vivo has been proposed because the nitric oxide inhibitor $\mathrm{N}$-monomethyl-L-arginine (NMLA) abolishes insulin secretion induced by ET-1 [8]. It is known that ET-1 is capable of stimulating nitric oxide production in perfused arterial vessels [24]. In our initial study, using isolated islets, it could be speculated that the endothelium still present in the islets play a part in the insulin release induced by ET-1. The present study clearly points to an important role for the alpha cells. The combined action of glucagon from 


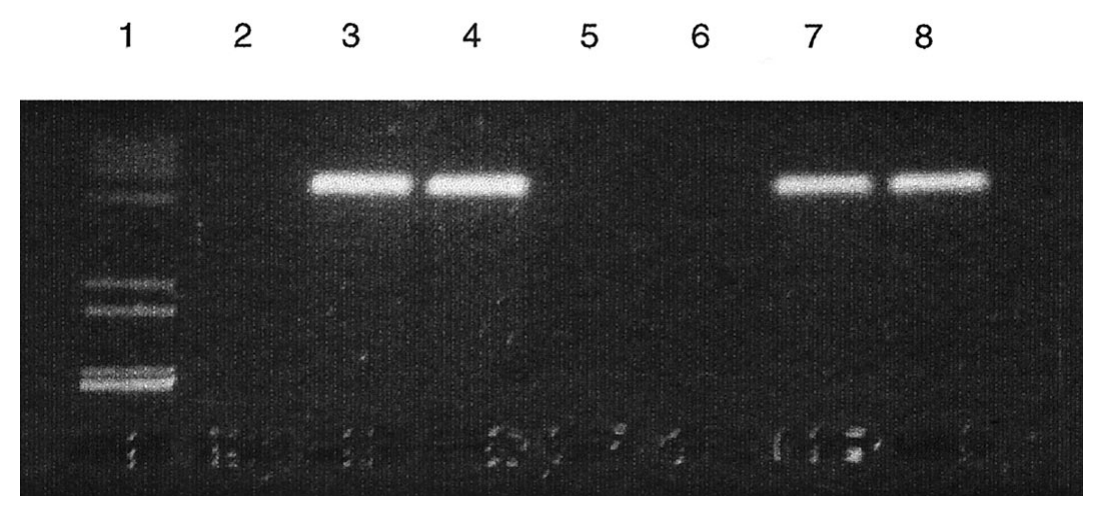

Fig.3. RT-PCR analysis of $\mathrm{ET}_{\mathrm{A}}$-receptor mRNA. Samples of the PCR reactions were fractionated in a $2 \%$ agarose gel. The gel stained with ethidiumbromide is shown. Lane: 1, size markers; 2, no reverse transcriptase added (negative control); 3-4, $\alpha \mathrm{TC} 1.9$ cells; $5-6$, INS-1 cells; 7-8, rat islets

the alpha cells and a substance derived from endothelium e.g. nitric oxide could, however, also be operating.

It is noteworthy that increased ET-1 immunoreactivity has been shown in chronic pancreatitis and, in particular, that ET-1 immunoreactivity is colocalized with insulin and glucagon [25]. Pancreatic ET can be released by intragastric alcohol as shown in the anaesthetized cat [26]. It is also known that ET can reduce pancreatic blood flow as shown in the dog [27]. In a recent study $\mathrm{ET}_{\mathrm{B}}$ receptor-like immunoreactivity on the rat islet beta and delta cells was reported [28]. Our present study clearly shows that no functional ET receptors exist on beta cells.

Note, our conclusions are not based on a single finding but rather on a number of different experiments all pointing in the same direction. Thus, it is hypothesized that ET-1 stimulates islet alpha cells to release glucagon which subsequently increases insulin secretion. It is proposed that a paracrine mechanism is responsible for insulin secretion induced by ET-1. The physiological and pathophysiological role of ET-1 on the endocrine pancreatic function is still to be clarified. It is clear, however, that this peptide is capable of changing islet secretion on a short-term basis. Whether a constant increased ET-1 concentration, presumably being present in pathological conditions such as hypertension and diabetes, might affect long-term islet hormone secretion in a deleterious direction is not known. The circulating ET concentrations in humans of 1-5 pmol/l are several orders of magnitude lower than the concentrations we applied in our islet cell experiments. It might well be, however, that an ET concentration in nanomolar range is achieved in the islets due to local release from the endothelium, e.g. in atherosclerosis vascular ET increases remarkably in the face of only a slight increase in circulating ET [29].
In conclusion, it is suggested that the insulinotropic effect of ET-1 is mediated by a paracrine action secondary to stimulation of glucagon release from ET-receptor mRNA positive alpha cells.

Acknowledgements. The authors acknowledge the skilled technical assistance of K. Eriksen, D. Rasmussen and L. Blak. The study was supported by the University of Aarhus, the Danish Diabetes Association, Institute for Experimental Clinical Research, Aarhus University. The INS-1 cells were kindly provided by Professor C.B. Wollheim, University of Geneva, Switzerland. $\alpha$ TC1.9 cells were obtained from Professor D. Hanahan, University of California, USA. MIN6 cells were kindly provided by Professor J. Miyazaki, Osaka Medical School, Japan.

\section{References}

1. Yanagisawa M, Kurihara H, Kimura S et al.(1988) A novel potent vasoconstrictor peptide produced by vascular endothelial cells. Nature 332: 411-415

2. Haak T, Jungmann E, Felber A, Hillmann U, Usadel KH (1992) Increased plasma levels of endothelin in diabetic patients with hypertension. Am J Hypertens 5: 161-166

3. Letizia C, Iannaccone A, Cerci S et al. (1997) Circulating endothelin-1 in non-insulin-dependent diabetic patients with retinopathy. Horm Metab Res 29: 247-251

4. Takahashi K, Ghatei MA, Lam HC, O'Halloran DJ, Bloom SR (1990) Elevated plasma endothelin in patients with diabetes mellitus. Diabetologia 33: 306-310

5. Bertello P, Veglio F, Pinna G, Gurioli L, Molino P, Alban S, Chiandussi L (1994) Plasma endothelin in NIDDM patients with and without complications. Diabetes Care 17: 574-577

6. Gregersen S, Thomsen JL, Brock B, Hermansen K (1996) Endothelin-1 stimulates insulin secretion by direct action on the islets of Langerhans in mice. Diabetologia 39: 1030-1035

7. Zimmerman RS, Maymind M (1995) Endothelin-1 decreases glucose, inhibits glucagon, and stimulates insulin release in the rat. Metabolism 44: 1321-1325

8. Zimmerman RS, Maymind M (1995) NG-methyl-L-arginine and somatostatin decrease glucose and insulin and block endothelin-1 (ET-1)-induced insulin release but not ET-1-induced hypoglycemia. Metabolism 44: 15321535

9. Juan CC, Fang VS, Huang YJ, Kwok CF, Hsu YP, Ho LT (1996) Endothelin-1 induces insulin resistance in conscious rats. Biochem Biophys Res Commun 227: 694-699 
10. Ottosson-Seeberger A, Lundberg JM, Alvestrand A, Ahlborg G (1997) Exogenous endothelin-1 causes peripheral insulin resistance in healthy humans. Acta Physiol Scand 161: 211-220

11. Josefsen K, Stenvang JP, Kindmark H et al. (1996) Fluorescence-activated cell sorted rat islet cells and studies of the insulin secretory process. J Endocrinol 149: 145-154

12. Asfari M, Janjic D, Meda P, Li G, Halban PA, Wollheim CB (1992) Establishment of 2-mercaptoethanol-dependent differentiated insulin- secreting cell lines. Endocrinology 130: $167-178$

13. Miyazaki J, Araki K, Yamato E et al. (1990) Establishment of a pancreatic beta cell line that retains glucose- inducible insulin secretion: special reference to expression of glucose transporter isoforms. Endocrinology 127: 126-132

14. Efrat S, Linde S, Kofod $\mathrm{H}$ et al. (1988) Beta-cell lines derived from transgenic mice expressing a hybrid insulin gene-oncogene. Proc Natl Acad Sci USA 85: 9037-9041

15. Powers AC, Efrat S, Mojsov S, Spector D, Habener JF, Hanahan D (1990) Proglucagon processing similar to normal islets in pancreatic alpha-like cell line derived from transgenic mouse tumor. Diabetes 39:406-414

16. Fernandez-Durango R, de Juan JA, Zimman H, Moya FJ, Garcia de la CM, Fernandez-Cruz A (1994) Identification of endothelin receptor subtype (ETB) in human cerebral cortex using subtype-selective ligands. J Neurochem 62: 1482-1488

17. Vierhapper H (1996) Effect of endothelin-1 in man-impact on basal and stimulated concentrations of luteinizing hormone, follicle-stimulating hormone, thyrotropin, growth hormone, corticotropin, and prolactin with and without pretreatment with nifedipine. Metabolism 45: 658-661

18. Fujii Y, Tomic M, Stojilkovic SS et al. (1995) Effects of endothelin-1 on $\mathrm{Ca} 2+$ signaling and secretion in parathyroid cells. J Bone Miner Res 10: 716-725

19. Conte D, Questino P, Fillo S, Nordio M, Isidori A, Romanelli F (1993) Endothelin stimulates testosterone secretion by rat Leydig cells. J Endocrinol 136:R1-R4
20. Masaki T (1993) Endothelins: homeostatic and compensatory actions in the circulatory and endocrine systems. Endocr Rev 14: 256-268

21. Donckier JE, Hanet C, Berbinschi A et al. (1991) Cardiovascular and endocrine effects of endothelin-1 at pathophysiological and pharmacological plasma concentrations in conscious dogs. Circulation 84: 2476-2484

22. Teuscher AU, Lerch M, Shaw S, Pacini G, Ferrari P, Weidmann P (1998) Endothelin-1 infusion inhibits plasma insulin responsiveness in normal men. J Hypertens 16: $1279-1284$

23. Yamato E, Ikegami H, Takekawa K et al. (1997) Tissuespecific and glucose-dependent expression of receptor genes for glucagon and glucagon-like peptide-1 (GLP-1). Horm Metab Res 29: 56-59

24. Warner TD, Mitchell JA, de Nucci G, Vane JR (1989) Endothelin-1 and endothelin-3 release EDRF from isolated perfused arterial vessels of the rat and rabbit. J Cardiovasc Pharmacol 13: 85-88

25. Kakugawa Y, Paraskevas S, Metrakos P et al. (1998) Alterations in pancreatic microcirculation and expression of endothelin-1 in a model of chronic pancreatitis. Pancreas 13: 89-95

26. Lewis MP, Reber PU, Kusske AM et al. (1998) Intragastric alcohol causes endothelin release from feline pancreas. Dig Dis Sci 43: 927-930

27. Takaori K, Inoue K, Kogire M et al. (1992) Effects of endothelin on microcirculation of the pancreas. Life Sci 51: 615-622

28. Yamamoto T, Uemura H (1998) Distribution of endothelin-B receptor-like immunoreactivity in rat brain, kidney, and pancreas. J Cardiovasc Pharmacol 31: 207-211

29. Lerman A, Edwards BS, Hallett JW, Heublein DM, Sandberg SM, Burnett JC (1991) Circulating and tissue endothelin immunoreactivity in advanced atherosclerosis. New Engl J Med 325: 997-1001 